\title{
Cálculo Mental e Ensino de Aritmética em Escolas da Cidade do Rio de Janeiro no Final do Século XIX
}

\author{
Mental Calculus and Arithmetic Teaching in Schools in Rio de Janeiro at \\ the End of the 19th Century
}

Flávia dos Santos Soares*

ORCID iD 0000-0003-0869-0838

\begin{abstract}
Resumo
O cálculo mental vem sendo considerado um recurso didático valorizado no Brasil, mais especialmente a partir de 1990, com a publicação de documentos que reforçaram sua importância para o ensino da Matemática na Escola Básica. Entretanto, sugestões para sua utilização já estavam presentes em recomendações curriculares para a escola primária e a secundária desde o século XIX. Incorporado a orientações para a aritmética, o cálculo mental aparece na esteira das propostas de renovação do ensino juntamente com as ideias do método intuitivo, a partir da década de 1870. Neste texto, tem-se como objetivo investigar de que forma o cálculo mental esteve presente nas prescrições para o ensino de aritmética e de que forma foi implementado na prática dos professores em escolas da cidade do Rio de Janeiro. Pretende-se destacar a importância do cálculo mental no ensino de aritmética nos últimos anos do século XIX em documentos oficiais e como o cálculo mental era apresentado em obras didáticas, programas e materiais de ensino.
\end{abstract}

Palavras-chave: Ensino de Aritmética. Cálculo Mental. Rio de Janeiro. Escolas Primárias e Secundárias. Século XIX.

\begin{abstract}
Mental calculus has been considered a didactic resource valued in Brazil, especially since 1990, with the publication of documents that reinforced its importance for Mathematics teaching in elementary education. However, suggestions for its use are already present in the curricular recommendations for elementary and secondary education since the 19th century. Incorporated into guidelines for arithmetic, mental calculus appears in the wake of proposals for teaching renewal together with the intuitive method ideas, beginning in the 1870s. In this text, the objective is to investigate how mental calculus was present in the prescriptions for the arithmetic teaching and how it was implemented in the teachers practice in schools in Rio de Janeiro. It is intended to highlight the importance of mental calculus in arithmetic teaching in the late nineteenth century in official documents and how mental calculus was presented in didactic works, programs and teaching materials.
\end{abstract}

Keywords: Arithmetic teaching. Mental calculus. Rio de Janeiro. Elementary and secondary education. Nineteenth century.

\section{Introdução}

\footnotetext{
* Doutora em Educação pela Pontifícia Universidade Católica do Rio de Janeiro (PUC-Rio). Professora da Faculdade de Educação da Universidade Federal Fluminense (UFF), Niterói, RJ, Brasil. Endereço para correspondência: Rua Conde de Bonfim, 25, apt. 711, Tijuca, Rio de Janeiro, RJ, Brasil, CEP: 20520-050. Email: flasoares.rlk@gmail.com.
} 
Em 1980, o National Council of Teachers of Mathematics (NCTM) dos Estados Unidos apresentou várias recomendações para o ensino de Matemática no documento An Agenda for Action: Recommendations for School Mathematics of the 1980's (NCTM, 1980). No documento, foi destacada a necessidade de trabalhar de modo que o aluno pudesse construir seus próprios conhecimentos, utilizasse a resolução de problemas na exploração da Matemática com base nos problemas vividos no cotidiano e empregasse o cálculo mental para ajudar a solucioná-los.

Essas orientações, acolhidas de modo favorável no contexto brasileiro, foram incorporadas nos Parâmetros Curriculares Nacionais (BRASIL, 1997) que estabeleceram, à época, propostas de novos caminhos para o ensino da disciplina de Matemática. Segundo a proposta, "os procedimentos do cálculo mental constituem a base do cálculo aritmético que se usa no cotidiano" (p. 76) e a prioridade em relação ao cálculo mental era de que os alunos pudessem construir e selecionar procedimentos adequados à situação-problema apresentada. $\mathrm{O}$ documento destacava ainda que o cálculo mental utiliza cálculos intermediários que facilitam a compreensão do cálculo escrito e que este, para ser compreendido, apoia-se no cálculo mental, nas estimativas e aproximações. Além disso, os exercícios de cálculo mental fazem com que, no decorrer do tempo, o aluno consiga utilizar as estratégias para o cálculo escrito.

A ideia mais comum que se tem por cálculo mental é entendê-lo como o cálculo feito com memorização da tabuada ou feito "de cabeça". Cortés (2001) considera que, em geral, existem três formas de fazer cálculos aritméticos: (a) escritos; (b) com métodos mentais; e (c) com algum dispositivo, como uma calculadora. Os cálculos escritos são realizados com lápis e papel e os cálculos mentais são um tipo de cálculo no qual não se utilizam papel e lápis ou qualquer outro implemento adicional, mas somente processos mentais. Para Parra (1996), entretanto, “o cálculo mental não exclui a utilização de papel e lápis, particularmente no registro de cálculos intermediários em um processo que é, essencialmente, mental” (p. 188), embora o uso da memória seja estimulado.

Ainda segundo Parra (1996), compreende-se que cálculo mental é:

o conjunto de procedimentos em que, uma vez analisados os dados a serem tratados, estes se articulam, sem recorrer a um algoritmo preestabelecido para obter resultados exatos ou aproximados. Os procedimentos de cálculo mental se apoiam nas propriedades do sistema de numeração decimal e nas propriedades das operações (PARRA, 1996, p. 189).

Dessa forma, não se enfatiza a rapidez na realização das contas, embora os processos utilizados no cálculo mental levem a um menor tempo gasto com as operações.

Ao definir o cálculo mental como um método alternativo aos algoritmos, Alfonso 
(2005) também salienta que não há, nas propriedades e nos princípios do sistema de numeração decimal, nada que diga que alguns cálculos são para fazer de cabeça e que outros são para fazer com lápis e papel. Para o autor, os métodos do cálculo mental não são basicamente diferentes dos métodos de cálculo escrito; portanto, não há uma linha divisória entre eles.

Mesmo considerando possíveis discrepâncias no que se entende por cálculo mental, sua inclusão como proposta de ensino na escola brasileira não é recente. A expressão esteve presente em recomendações curriculares e programas para a escola primária e secundária brasileira desde o século XIX como uma das estratégias a serem utilizadas no ensino de aritmética. Sua inserção no ensino brasileiro se alinhou com as primeiras manifestações de renovações no ensino desse campo juntamente com as ideias do método intuitivo, especialmente a partir de 1870.

Este texto tem como objetivo investigar de que forma o cálculo mental esteve presente em propostas para o ensino de aritmética e como foi implementado por professores em escolas da cidade do Rio de Janeiro. Pretende-se destacar sua importância nos debates sobre o ensino de aritmética nos anos finais do século XIX, a partir das prescrições da legislação oficial, de artigos da imprensa e materiais de ensino.

\section{Ensino de aritmética e cálculo mental em escolas da cidade do Rio de Janeiro}

A primeira lei para a instrução pública instituída no País é datada de 15 de outubro de 1827. Por meio dessa medida, criaram-se escolas ${ }^{1}$ de primeiras letras nos lugares mais populosos da nação e estas deviam seguir o ensino mútuo ${ }^{2}$. Quanto às matérias de ensino, recomendava-se que:

\footnotetext{
${ }^{1}$ Durante o século XIX, o ensino ainda se organizava por meio de aulas isoladas e as escolas funcionavam de improviso. Essas escolas eram montadas em espaços alternativos ou na casa do mestre que, mesmo quando era pago pelo Estado, na maioria das vezes custeava as despesas com aluguel e materiais didáticos (FARIA FILHO; VIDAL, 2000). Com exceção dos colégios religiosos e militares, o Colégio Pedro II e os liceus instituídos a partir da segunda metade do século XIX, não havia edifícios escolares. Somente na última década século, foi-se "reforçando a representação de que a construção de prédios específicos para a escola era imprescindível a uma ação eficaz junto as crianças" (p. 23) e que permitissem acolher o ensino seriado e delimitar o tempo escolar (FARIA FILHO; VIDAL, 2000).

${ }^{2} \mathrm{O}$ método mútuo teve sua origem na Inglaterra, no final do século XVIII, sendo posteriormente adotado na França e em outros países europeus e chegou à América Latina na primeira metade do século XIX. Seus precursores foram Andrew Bell e Joseph Lancaster. A característica principal para o "sucesso" do método era a participação dos alunos. As classes eram dirigidas por um monitor, ou seja, um aluno mais "inteligente" que se destacava aos olhos do professor dentro de uma classe e "aprendia" mais rápido a lição. Antes do início da aula, o professor dava indicações e orientações particulares para o monitor, que, durante a aula, transmitia aos demais colegas o que o professor havia dito e fazia-os repetir a lição até que estes a soubessem de cor. O método mútuo
} 
os professores ensinarão a ler, escrever as quatro operações de arithmetica, pratica de quebrados, decimaes e proporções, as noções mais geraes de geometria pratica, a grammatica da lingua nacional, e os principios de moral christã e da doutrina da religião catholica e apostolica romana (BRASIL, 1827, Art. 6) ${ }^{3}$.

Evidencia-se no texto da lei que a aritmética estava presente nas orientações para a escola primária como matéria de ensino. Como lembra Oliveira (2011), deve-se, entretanto, compreender a aritmética em sentido mais amplo:

[...] a palavra "aritmética" era empregada para o ensino de conhecimentos numéricos básicos que envolviam quatro operações, regra de três, números decimais, sistema de pesos e medidas e outros aprendizados de cálculo. A expressão "matemática", por sua vez, era também empregada, mas para os estudos mais complexos que envolvessem equações e conhecimentos similares. A geometria ${ }^{4}$, compondo o elenco dos conteúdos, não estava inserida nos estudos aritméticos ou matemáticos, pois pertencia a outra esfera de conhecimento das ciências exatas, embora dependente dos conhecimentos aritméticos para sua compreensão, como ocorria com o ensino de desenho linear e nivelamento (OLIVEIRA, 2011, p. 29).

Em comparação com a Lei de 1827, a Reforma de Couto Ferraz, estabelecida anos depois por meio do Decreto n. 1331A, de 1854, trouxe significativo aumento nos conteúdos ensinados nas escolas primárias no que diz respeito aos conhecimentos ligados à Matemática. As escolas públicas foram divididas em duas classes: uma de instrução elementar (escolas do primeiro grau) e outra de instrução primária superior (escolas do segundo grau). Para as primeiras, eram ensinados os princípios elementares da aritmética e o sistema de pesos e medidas do Município. Para as segundas ${ }^{5}$, estava prescrito o desenvolvimento da aritmética em suas aplicações práticas, a geometria elementar e um estudo mais desenvolvido do sistema de pesos e medidas, não só do Município da Corte, como de outras províncias do Império e das nações com as quais o Brasil mantinha relações comerciais.

era baseado na repetição e no adestramento, mas proibia, entretanto, o uso de tabuadas. No Brasil, o método mútuo foi adotado por vários anos, mesmo depois do expediente do ministro do Império Campos Vergueiro, baixado em 1833, abolindo o método de ensino pelo sistema. Para outras informações sobre o ensino mútuo ver o texto de Bastos (1999).

${ }^{3}$ Em todo o texto, será mantida a grafia original, conforme consta nos documentos e obras citadas.

${ }^{4}$ Moacyr (1936) relata alguns debates ocorridos entre deputados sobre a pertinência do ensino de geometria na escola primária. Em sua redação definitiva, a lei manteve como matéria de ensino a aritmética apenas nas escolas para meninos. Para as escolas femininas, as mestras deveriam cumprir o que constava no Art. 6, com exclusão das noções de geometria e limitar a instrução de aritmética só às suas quatro operações.

${ }^{5}$ No Relatório da Instrucção Primaria e Secundaria do Município da Corte, do ano de 1884, o Inspetor Geral interino João Pedro Belfort Vieira afirma que "O Município da Corte ainda não possue escolas publicas primarias do segundo grau, não obstante o que determina a esse respeito o regulamento orgânico annexo ao Decreto n. 1331 A, de 17 de fevereiro de 1854" (MUNICÍPIO, 1885, Anexo C, p. 3). Como lembra Castanha (2013), o estabelecimento de escolas de segundo grau foi bastante dificultado pelo baixo nível intelectual dos candidatos a professor e estes conhecimentos só estavam presentes nas escolas secundárias ou em alguns colégios particulares. Assim, o que vigorou de fato nas escolas públicas primárias foi o ensino da aritmética. A geometria, mesmo constando na legislação, está ausente, por exemplo, dos conteúdos exigidos nas provas dos concursos para professores de primeiras letras realizados na Corte do Rio de Janeiro durante o século XIX (Cf. SOARES, 2007). 
Quanto ao método de ensino, o regulamento previa o ensino simultâneo ${ }^{6}$ mas podia "todavia o inspector geral ouvindo o conselho director determinar, quando o julgue conviniente, que se adopte outro em qualquer parochia, conforme os seus recursos e necessidades" (BRASIL, 1854, Art. 73).

Mas como verificar de que forma essas prescrições foram atendidas pelos professores nas escolas?

A reforma de Couto Ferraz estabeleceu, em seu primeiro título, condições para a Inspecção dos estabelecimentos publicos e particulares de instrucção primaria e secundaria. Esta era exercida por um corpo de inspeção formado pelo ministro do Império, por um inspetor geral, por um Conselho Diretor e por delegados de distrito ${ }^{7}$.

Cabia ao inspetor geral, entre outras atribuições: inspecionar as escolas; presidir exames de capacidade para o magistério; autorizar a abertura de escolas; corrigir ou substituir os compêndios adotados nas escolas públicas; coordenar a estatística anual das províncias; apresentar relatório referente ao estado da instrução nas províncias e na Corte, bem como o orçamento anual da receita e despesa com a instrução a seu cargo.

Aos delegados, cabia inspecionar as escolas públicas de seus distritos, verificar se elas cumpriam a legislação vigente e prestar conta ao inspetor geral do que observassem. Entre as questões a serem observadas estavam as condições físicas das escolas, os livros utilizados e o ensino das diferentes matérias, entre elas a aritmética. Contudo, até a década de 1870 nenhuma comissão havia sido constituída para tal fim e dados organizados sobre as escolas ainda não haviam sido obtidos.

Algumas informações sobre o que era ensinado nas escolas podem, entretanto, ser obtidas por outras fontes. Em relação aos conteúdos de aritmética, há referências que indicam a presença do cálculo mental como prática no ensino da aritmética utilizada por professores, conforme se nota em anúncios na imprensa da época que indicam o programa seguido em escolas particulares.

\footnotetext{
${ }^{6}$ Antônio de Almeida Oliveira, em seu livro $O$ ensino público, diz que o ensino simultâneo "foi inventado por Delasalle, consiste em instruir ao mesmo tempo todos os alunos de uma só classe, e tem grande uso pelas vantagens que apresenta. Ele não fatiga o mestre, põe-no em contato com toda a aula e mantém a emulação dos alunos. Mas esse modo não pode ser aplicado se não até certo número de alunos. Os pedagogistas o fixam ordinariamente em 60" (2003, p. 256).

${ }^{7}$ As competências do ministro, do inspetor geral, dos delegados e do Conselho Diretor encontram-se discutidas com mais detalhes em Gondra, Garcia e Sacramento (2000).
} 
O jornal Correio da Tarde ${ }^{8}$, em maio de 1862, divulgou nota que informava sobre um curso noturno de dois professores que "ensinarão matemáticas, câmbios, cálculo mental, escrituração mercantil e caligrafia". O curso foi anunciado sob a responsabilidade dos professores Eduardo de Sá ${ }^{9}$ e Benjamin Constant ${ }^{10}$.
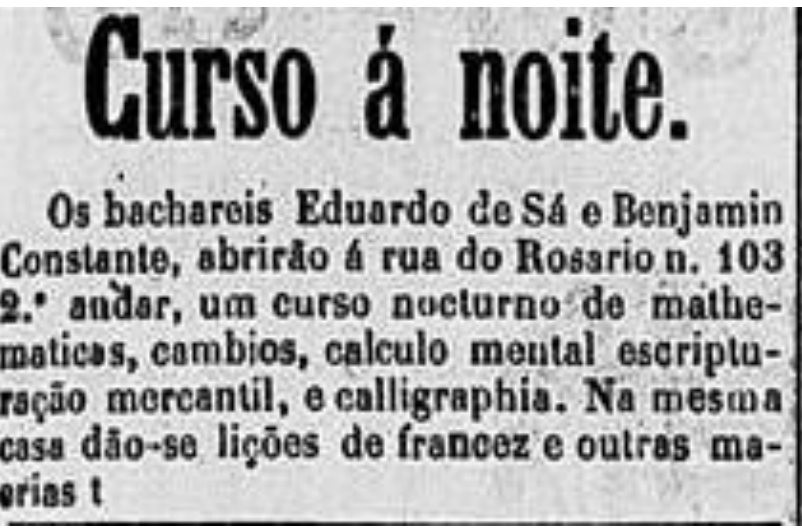

Figura 1 - Anúncio de curso de cálculo mental Fonte: CORREIO (1862, p. 3)

Em 1871, o ministro do Império João Alfredo Corrêa de Oliveira, em seu Relatório Anual, manifestou-se insatisfeito com o estado da instrução pública do Brasil, comparativamente a outros países.

\begin{abstract}
Não temos infelizmente acompanhado o grande movimento da civilização moderna em relação á instrucção pública. Quasi estacionaria tem-se esta conservado entre nós, ao passo que se empenham todos os esforços e nenhum sacrifício se poupa para dar-lhe o mais amplo desenvolvimento nos paizes onde se tem comprehendido toda a sua importância, reflectindo-se que ella não só eleva o indivíduo pelo aperfeiçoamento de suas faculdades moraes, como é o mais poderoso elemento de engrandecimento e prosperidade nacional, e condição essencial do exercício regular das instituições livres (BRASIL, 1871, p. 9).
\end{abstract}

Em ofício de julho de 1872, o inspetor geral da Instrução Primária e Secundária do Município da Corte, José Bento da Cunha Figueiredo, determinou que os professores remetessem os programas de ensino de suas respectivas escolas referentes ao ensino das

8 Disponível na Hemeroteca Digital Brasileira, da Biblioteca Nacional, em: http://memoria.bn.br/hdb/per iodo.aspx.

${ }^{9}$ Segundo Blake (1970), Eduardo de Sá Pereira de Castro nasceu na Bahia em 1828 e faleceu no Rio de Janeiro em 1872. Era bacharel em Matemática e Ciências Físicas e foi lente da Escola Militar. Durante oito anos dirigiu um colégio para meninos, o Collegio S. Sebastião. Atuou também no Colégio Pedro II como repetidor e como professor do Externato. É autor do livro Explicador de Arithmetica, publicado em 1854; do Compendio de Metrologia, publicado em 1863, entre outras obras.

${ }^{10}$ Benjamim Constant Botelho de Magalhães (1836-1891) era bacharel em Ciências Físicas e Matemática. Foi repetidor interino no Internato do Colégio Pedro II, professor de matemáticas elementares do Imperial Instituto dos Meninos Cegos, do Instituto Comercial, da Escola Militar, diretor e professor de matemáticas elementares e escrituração mercantil da Escola Normal da Corte. Seguiu ainda a carreira militar participando da Guerra do Paraguai como engenheiro e destacou-se como articulador da Proclamação da República, o que o fez ser promovido a Ministro da Guerra e depois a Ministro da Instrução Pública, Correios e Telégrafos. Foi adepto do positivismo, corrente filosófica, fundada por Augusto Comte em Paris, que o influenciou nas propostas que implementou na Escola Normal e no Instituto dos Meninos Cegos e também em sua vida pessoal e política. 
seguintes matérias: instrução moral e religiosa, leitura, noções essenciais da gramática portuguesa, princípios elementares de aritmética e sistema métrico decimal. O inspetor solicitou que os professores declarassem a distribuição das matérias ao longo dos anos, o que tratava cada lição, o tempo destinado a ela e outras "informações que entendesse convenientes para o melhor esclarecimento do assumpto relativo á instrucção primária do $1^{\circ}$ gráo" (MUNICÍPIO, 1872, p. 9).

Em resposta, alguns professores indicaram suas preferências quanto ao método de ensino. Uma das professoras, Delphina Rosa da Silva, disse não subordinar suas aulas a um único método, no caso, nem totalmente ao método individual ou ao simultâneo. Outro professor, Olympio Catão Viriato Montez, ponderou sobre os inconvenientes do método simultâneo; disse seguir "um mixto do que ha de melhor nos methodos simultâneo e mutuo" (MUNICÍPIO, 1872, Anexo 4, p. 9).

Alguns professores mencionaram ministrar aulas de aritmética duas vezes na semana, às terças e quintas; outros, três vezes, às terças, quintas e sábados.

Para as aulas, Augusto Candido Xavier Cony alegou que preferia "o systema de Rapet $^{11}$ para o ensino da arithmetica" (MUNICÍPIO, 1872, Anexo 4, p. 10); Philippe de Barros Vasconcellos disse ser "preferível o methodo de Pestalozzi ${ }^{12}$ para o ensino da arithmetica aos alunos do $1^{\circ}$ anno" (ibidem), método este que adotava na escola sob sua direção.

Candido Matheus de Faria Pardal e outros professores responderam em bloco; o professor Pardal, encarregado de organizar um resumo das opiniões dos professores, apresentou sua proposta de estudos para as escolas municipais da Corte, segundo ele já em prática na escola na qual era diretor. Na escola de meninos que Pardal dirigia, as aulas de aritmética no primeiro ano eram frequentes e com duração de uma hora em todos os dias da semana, com exceção das quartas-feiras.

\footnotetext{
11 Teixeira (2014) cita o livro "Sistema de Rapet - Arithmetica", do autor "Rapet", que entendemos ser o autor referido por Cony. Não localizamos outras informações sobre a obra nem sobre o método citado.

${ }^{12}$ Mesquida (2016) esclarece que, a rigor, o método de Pestalozzi não é somente o uso de técnicas de ensino ou de instrumentos didático-pedagógicos, mas o conjunto da teoria e da prática pedagógica, incluindo a filosofia, a psicologia e a política da educação. "O Método visa a formação do ser humano integral, na sua completude, insistindo junto ao educador que a "intuição", isto é, a "indução", como diríamos hoje, é o meio pelo qual a prática pedagógica deve ser desenvolvida, partindo do concreto para o abstrato, do sensível, da experiência, para a teoria, progressivamente" (p. 24).
} 


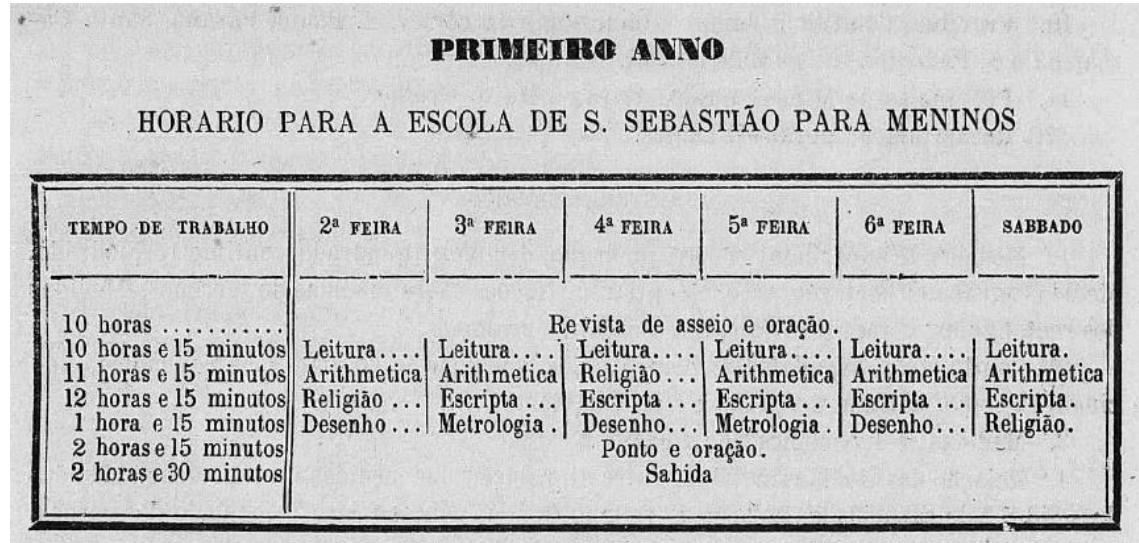

Figura 2 - Horário de estudos para o $1^{\circ}$ ano para a Escola de S. Sebastião para meninos, dirigida por Candido Matheus de Faria Pardal Fonte: Município (1872, Anexo 11, p. 38)

O programa de estudos apresentado para as escolas municipais da Corte, elaborado por Pardal, estava dividido em três anos. No primeiro ano, ensinava-se instrução religiosa, leitura, escrita, sistema métrico, desenho linear e, na aritmética, o "calculo mental e escripto". No segundo ano, as mesmas matérias eram ensinadas com outros conteúdos. No terceiro ano, no lugar da leitura e escrita, figurava a gramática e se ensinava geografia.

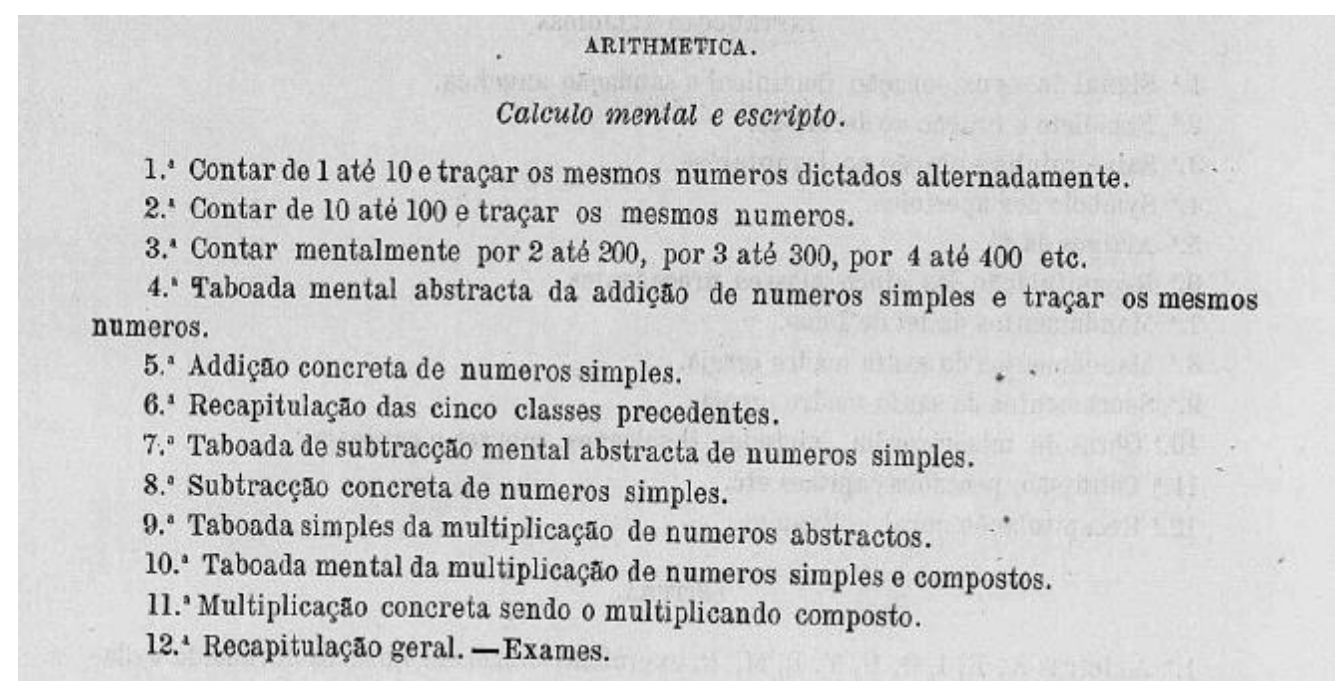

Figura 3 - Programa de Arithmetica para as escolas municipaes da Corte feito pelo seu diretor Candido Matheus de Faria Pardal ( $1^{\circ}$ ano $)$

Fonte: Município (1872, Anexo 11, p. 32)

Outro curso que mencionava textualmente o ensino do cálculo mental era o da escola noturna de adultos da Sociedade Auxiliadora da Indústria Nacional (SAIN). Fundada em 15 de abril de 1867, mas somente inaugurada em maio de 1871, o objetivo da escola era preparar "os homens para ingressar na escola industrial, também mantida pela SAIN, que poderiam então modernizar a indústria nacional, especialmente a agrícola, e assim inserir o Brasil na 
rota da civilização" (MIZUTA, 2011, p. 36). Consta como professor o nome de Camillo de Lellis e Silva ${ }^{13}$, e o método indicado era o simultâneo.

\section{ESCOLA NOCTURNA DE ADULTOS DA SOCIEDADE AUXILIADORA DA INDUSTRIA NACIONAL}

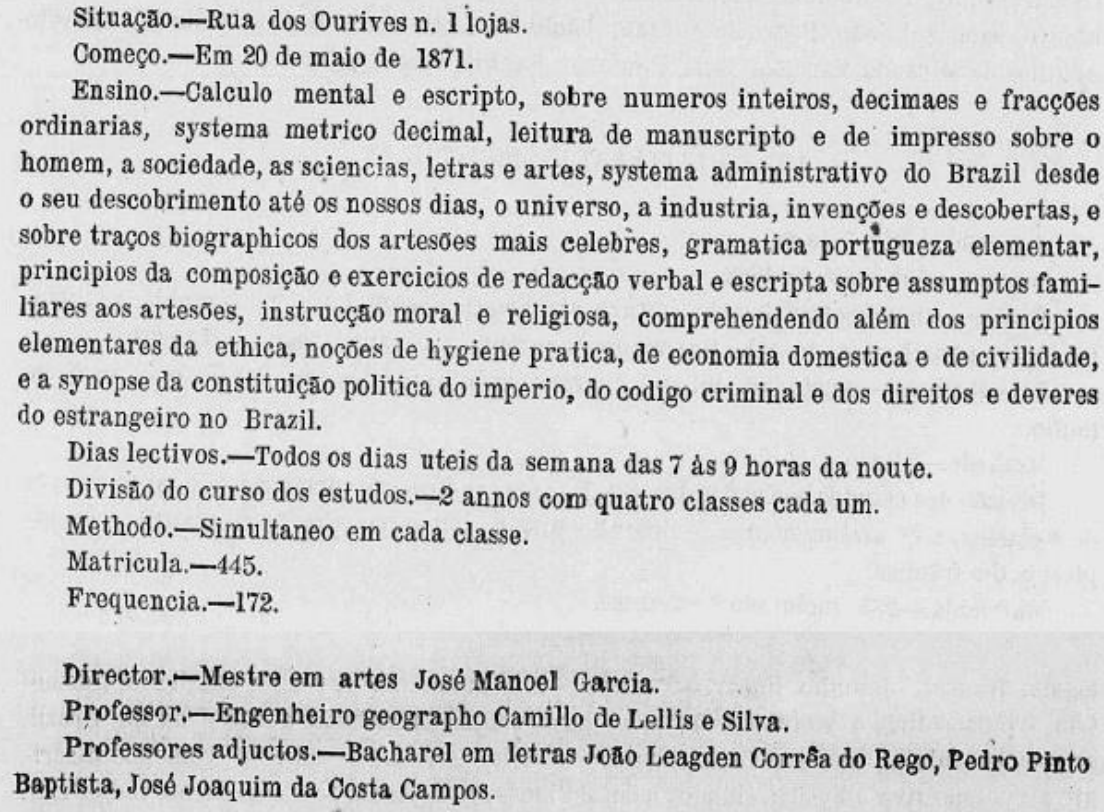

Figura 4 - Programa da Escola Noturna de Adultos da SIAN Fonte: Município (1872, Anexo 7, p. 18-19)

No Relatório referente ao ano de 1873, o inspetor geral interino Antonio Felix Martins informou que finalmente, conforme recomendado no Decreto de 1854 , uma comissão ${ }^{14}$ havia sido constituída e começaria seu trabalho nas escolas públicas (MUNICÍPIO, 1874). No relato sobre o trabalho da comissão ${ }^{15}$, particularmente quanto ao ensino da aritmética, o cálculo mental foi reconhecido como importante recurso ao ensino, embora fosse constatado seu pouco uso nas escolas.

O cálculo mental, que devia preceder ao estudo da arithmetica propriamente dita, não é empregado nas escolas, desprezando-se assim um importante recurso para o desenvolvimento da intelligencia. Definições, regras, e até operações decoradas, foi o que, na quasi generalidade, das escolas, a commissão presenciou (MUNICÍPIO, 1874, Anexo 3, p. 44).

\footnotetext{
${ }^{13}$ Camillo de Lellis e Silva era graduado em Ciências Físicas e Naturais e engenheiro formado pela Escola Central. Atuou como engenheiro da Empresa de Carris de Ferro de Santa Thereza, foi examinador da instrução pública e professor substituto de Matemáticas do Colégio Pedro II.

${ }^{14}$ A comissão era composta pelos professores Philippe da Motta de Azevedo Corrêa, membro do Conselho Diretor e professor do Colégio Pedro II; José Manuel Garcia, também professor do Colégio Pedro II; João Rodrigues da Fonseca Jordão, professor público primário, e pelo inspetor geral, José Bento da Cunha Figueiredo. ${ }^{15} \mathrm{O}$ Relatório apresentado ao conselheiro inspector geral da instrucção primaria e secundária do município da Corte pela comissão visitadora das escolas púbicas e estabelecimentos particulares de instruç̧ão primária e secundária do mesmo município é o Anexo 3 do Relatório da Inspectoria Geral da instrucção primária e secundária do Município da Corte (MUNICÍPIO, 1874), que por sua vez faz parte do Relatório do Ministro do Império do ano de 1873 (BRASIL, 1874).
} 
Frente a essa situação, a comissão recomendou que:

Depois do conhecimento da numeração passar-se-ha ao calculo mental o depois ao escripto seguido então do estudo das theorias. Conhecido o mechanismo das fracções decimaes, cujo estudo alguns pedagogistas aconselham que se faça juntamente com o dos números inteiros, passar-se-ha ao desenvolvimento do systema métrico, que já deve ser conhecido praticamente pelos alunos (MUNICÍPIO, 1874, Anexo 3, p. 45).

No Relatório, a comissão descreveu o estado precário dos edifícios que abrigavam as escolas e dos móveis e utensílios, cujo "estado é mais lamentável” (MUNICÍPIO, 1874, Anexo 3, p.24).

Como foi ressaltado pela comissão,

não é só boa mobília que constitue o material da escola; se ella é um accessorio importantissimo, não é o único necessário; a par della torna-se saliente e indispensável aquella parte do material, que tem íntima e directa ligação com o ensino (MUNICÍPIO, 1874, Anexo 3, p. 36).

Apesar de nenhuma escola da Corte ter todos os objetos prescritos pelo regimento interno das escolas ${ }^{16}$, a comissão constatou que algumas delas possuíam materiais específicos disponíveis para o ensino da aritmética.

Em relação ao método de ensino, já havia sinalização de que o intuitivo era o que devia ser seguido na disciplina; para isso, as escolas estavam sendo providas de material apropriado $^{17}$.

O final do século XIX marcou um momento importante na difusão de várias tecnologias inventadas com a aplicação dos conhecimentos científicos até então acumulados. Era então o momento de modernizar as práticas escolares, contemplando nessa proposta a inserção de diferentes objetos destinados ao ensino primário da arithmetica e do sistema métrico decimal (PAIS, 2014, p. 4).

No relatório, a comissão informou que, por iniciativa da Inspetoria Geral, as escolas estavam começando a serem dotadas com contadores mecânicos ${ }^{18}$ "como meio de facilitar o estudo da numeração" (MUNICÍPIO, 1874, Anexo 3, p. 36) e que "ainda não tem tido a

\footnotetext{
${ }^{16} \mathrm{O}$ relatório da comissão menciona o regimento de 02 de maio de 1855 , que não foi localizado por nós. Entretanto, outro documento, intitulado Regimento Interno para as Escolas Públicas de Instrução Primária, publicado junto com a Portaria n. 317, de 20 de outubro de 1855 (Cf. CASTANHA, 2013), previa: “Art. 7. Cada Escola deve ter os seguintes objetos: a imagem do Senhor Crucificado; o retrato de S. M. o Imperador, um relógio, um armário, uma mesa com estrado e uma cadeira de braços para o professor, cadeiras para as pessoas que forem visitar a escola, bancos e mesas inclinadas com tinteiro fixo; uma ampulheta, um mapa do Brasil e outro da Província do Rio de Janeiro; um quadro grande de madeira pintado de preto, esponjas e giz para os exercícios de aritmética e ortografia; um quadro ou mapa com o sistema legal de pesos e medidas e dos valores das moedas do Império, quadros para a leitura e outros com modelos de escrita; ardósia; papel; e compêndios para os meninos pobres; ponteiros; cabides para chapeus; réguas com guarnição de metal; talha para água; vasilhas menores".

${ }^{17}$ As relações dos materiais fornecidos às escolas estão presentes no Relatório da Comissão.

${ }^{18}$ Sobre o contador mecânico, trataremos mais adiante neste texto. Ver ainda o artigo de Pais (2014).
} 
applicação útil que devem ter" (O GLOBO, 1874, p. 3) ${ }^{19}$. Em algumas escolas já se notava a existência de instrumentos para o ensino da aritmética. Na primeira escola de meninos da Freguesia da Glória ${ }^{20}$ identificou-se a presença de "uma caixa de pesos e medidas de Carpentier"21 e um “contador mechanico" (MUNICÍPIO, 1874, Anexo 3, p. 30).

A crítica, entretanto, foi quanto ao uso precário do material pelo professor.

Quasi todas as escolas possuem actualmente uma caixa com os pesos e medidas do systema actual; mas em vez de estarem estes a vista dos alumnos, para acostumal-os, ao menos pela vista, a conhecel-los, e a comparar sua forma diversa e grandeza relativa, provocando-lhes também por este meio a atenção e o desejo de saber o uso e aplicação deles, são conservados dentro da respectiva caixa, e raras vezes vistos mesmo pelos alunos da $8^{\mathrm{a}}$ classe, que são os únicos aos quaes se dá conhecimento do systema métrico (MUNICÍPIO, 1874, Anexo 3, p. 36).

Para o ensino do sistema de pesos e medidas:

[...] é certo que não se poderá dar a esse ensino todo o desenvolvimento, nem as crianças carecem d'elle com toda perfeição; é mister, porém, que se lhes torne conhecido materialmente cada um dos pesos e medidas atuaes, fazer-lhes praticar certas operações d'onde resulte a comparação com os pesos antigos e o conhecimento do valor e da capacidade de cada um deles [...]. Com o apparelho Carpentier que hoje existe em todas as escolas, e com um mappa descriptivo e comparativo das diversas medidas, se obterá o resultado desejado (MUNICÍPIO, 1874, Anexo 3, p. 45).

As críticas dos delegados quanto à importância do cálculo mental, feitas nas visitas às escolas, parecem ter sido acatadas como recomendação aos professores. Em um artigo publicado no jornal Diário do Rio de Janeiro, o Collegio Pujol ${ }^{22}$ divulgou seu programa de estudos para o curso primário para o ano de 1875 e aconselhou:

O cálculo mental deve preceder o estudo da aritmética propriamente dita. Cada lição de calculo deve sempre ser precedida e seguida de exercícios de cálculo mental [...] O cálculo mental fixa a atenção das crianças, desenvolve a memória, forma o juízo

${ }^{19}$ Disponível na Hemeroteca Digital Brasileira, da Biblioteca Nacional em: http://memoria.bn.br/hdb/perio do.aspx.

${ }^{20}$ No Rio de Janeiro do século XIX, vigorava a divisão urbana por "freguesias", o que se assemelha ao que hoje se entende como bairro. Instauradas desde o Brasil Colônia, as "freguesias" ou "paróquias" correspondiam à menor unidade administrativa na qual estava organizada a cidade. As províncias, no território brasileiro (atuais estados), eram divididas em municípios, que por sua vez eram divididos em freguesias. "Contando com o mínimo de dez casas ou famílias, estas unidades, as menores da administração pública, eram áreas submetidas à jurisdição espiritual de um cura que também exercia o governo civil" (FRIDMAN, 2011). A "freguesia da Glória" estava organizada na região circunvizinha à Igreja de Nossa Senhora da Glória do Outeiro, no atual bairro da Glória, região próxima aos atuais bairros do Catete e Largo do Machado, na zona sul da cidade do Rio de Janeiro.

${ }^{21}$ Segundo Bastos (2010), no século XIX Marie Pape-Carpantier (1815-1878) teve significativa importância para a Educação Infantil e para a orientação de modelos de mobílias para as escolas. Para acompanhar sua vasta obra impressa, também criou vários materiais didáticos para auxiliar no desenvolvimento do método natural, isto é, "obter pelos sentidos, pela intuição, os julgamentos mais próximos da verdade" (BASTOS, 2010, p. 32).

${ }^{22}$ Publicado em 01 de janeiro de 1875. Disponível na Hemeroteca Digital Brasileira, da Biblioteca Nacional em: http://memoria.bn.br/hdb/periodo.aspx. O Colégio Pujol foi inaugurado em 21 de novembro de 1868 e funcionava no bairro de São Cristóvão, na cidade do Rio de Janeiro, sob a direção de Hyppólito Gustavo Pujol, professor habilitado e autorizado pelo Conselho de Instrução Pública da Província do Rio de Janeiro e pelo município neutro da Corte. 
[...] Recomendamos a nossos professores primários a não dar princípio ao cálculo escrito senão quando seus alunos já foram adiantados no cálculo mental (p. 3).

Como observa Souza (2000), no decorrer do século XIX, conteúdos e métodos de ensino fizeram parte das discussões sobre a questão política da educação popular ${ }^{23}$, os meios para efetivá-la, nesse debate, e a melhor organização pedagógica para a escola primária.

Em toda parte, difundiu-se a crença no poder da escola como fator de progresso, modernização e mudança social. A ideia de uma escola nova para a formação do homem novo articulou-se com as exigências do desenvolvimento industrial e o processo de urbanização. O fenômeno de âmbito mundial foi alimentado pela circulação de ideias e modelos gerados nos países ditos "civilizados" na época. Os mais variados temas da organização escolar tornaram-se objeto da reflexão política e pedagógica: métodos de ensino, a ampliação dos programas com a inclusão de novas disciplinas, livros e manuais didáticos, a classificação dos alunos, a distribuição dos conteúdos e do emprego do tempo, o mobiliário, materiais escolares, certificados de estudos, a arquitetura, a formação de professores, a disciplina escolar (p. 11).

$\mathrm{Na}$ esteira das propostas de renovação, a adoção de novos métodos e a inclusão de conteúdos nos programas de ensino foram demandas que passaram também a fazer parte da agenda de modernização da escola:

a introdução de novas disciplinas nos programas do ensino primário, especialmente ciências, desenho e educação física, articulou-se com a linguagem da modernidade, isto é, a justificativa para a inclusão desses conteúdos culturais assinalava as contribuições que eles trariam para a modernização. Dessa forma, a construção dos Estados-nação e a modernização social tornaram-se os pilares sobre os quais se alicerçaram os ideais e as políticas de inovação educacional no final do século XIX e início do século XX (SOUZA, 2000, p. 12).

O método intuitivo ou lições de $\operatorname{coisas}^{24}$ consistiu o núcleo principal da então renovação pedagógica proposta.

O ensino pelo método intuitivo aparecia como pedra angular na renovação dos métodos da escola elementar. Até este período, a gradação de conhecimentos não previa uma idade ideal de aprendizagem nem pressupunha uma paridade entre os vários saberes escolares. A partir de então, propunha-se o uso de duas ordens de método: o de organização dos alunos na classe, simultâneo [...] e o de organização dos saberes, intuitivo (SILVA; MACHADO, 2014, p. 200).

\footnotetext{
${ }^{23}$ Em seu artigo, Souza (2000) esclarece que: "Desde a segunda metade do século XIX, a questão política da educação popular envolveu, em todo o Ocidente, a discussão sobre a organização administrativa e didáticopedagógica do ensino primário. Tratou-se de definir as finalidades da escola primária e os meios de sua universalização. Esse processo implicou debates acerca da democratização da cultura e da função política da escola nas sociedades modernas. Dessa forma, a discussão sobre o conteúdo da escolarização popular tornou-se uma temática central e oscilou em decorrência de diferentes interesses políticos, ideológicos, religiosos, sociais, econômicos e culturais" (p. 9).

${ }^{24}$ As lições de coisas, forma pela qual o método de ensino intuitivo foi vulgarizado, é, de acordo com Buisson (apud SCHELBAUER, 2005), a primeira forma de intuição ou intuição sensível, aquela que é feita pelos sentidos. Ainda de acordo com Buisson, o termo foi popularizado pela Mme. Pape-Carpentier e empregado oficialmente durante suas conferências proferidas aos professores presentes na Exposição Universal de Paris, em 1867.
} 
O método pressupunha uma abordagem pautada na intuição, "pela qual o ensino deveria partir do particular para o geral, do conhecido para o desconhecido, do concreto para o abstrato" (SOUZA, 2000, p.12).

Segundo Valdemarin (2006), as proposições constitutivas do método de ensino intuitivo foram adotadas na segunda metade do século XIX em escolas europeias, americanas e brasileiras. A implantação do método intuitivo no Brasil ocorreu, dentre outras formas, pela publicação de manuais didáticos dirigidos a professores, destacando-se no Brasil o livro de Norman Allison Calkins. Como lembra Gomes (2011), a tradução feita por Rui Barbosa do manual de Calkins é vista como uma das estratégias mais importantes na disseminação do método no Brasil. Publicado originalmente nos Estados Unidos em 1861 e em 1886 no Rio de Janeiro pela Imprensa Nacional, o livro recebeu aqui o título de Primeiras lições de coisas: Manual de ensino elementar para uso dos pais e professores.

Sobre o método intuitivo, Gomes (2011, p. 56) recorda que:

[...] os defensores do método intuitivo argumentavam em favor da observação de fatos e objetos pelos estudantes, envolvidos em situações de aprendizagem em que o conhecimento não seria simplesmente transmitido e guardado de cor, mas surgiria no entendimento da criança a partir do instrumento proporcionado pela experiência dos sentidos.

Mesmo antes da publicação do manual de Calkins, pode-se notar no Brasil, como já foi dito, indícios da presença do método nas escolas e menção a ele a partir da década de 1870. Em função de suas ideias referentes à educação das crianças, o nome de Pestalozzi ${ }^{25}$ começou a aparecer na fala dos professores como um dos defensores do uso de objetos concretos para a aprendizagem e da intuição no ensino, considerada esta como "fundamento de todo o conhecimento e o princípio da instrução que deve ser respeitado por qualquer forma de ensino que se utilize" (COSTA, 2014, p. 43).

Em 1872, a importância dada a Pestalozzi como um dos defensores do método intuitivo no contexto de modernização do ensino de Matemática pode ser vista em artigos da imprensa periódica, como no artigo "A arithmetica", escrito por Manuel Ribeiro de Almeida ${ }^{26}$,

\footnotetext{
${ }^{25}$ Johann Heinrich Pestalozzi (1746-1827), pedagogo e pensador suíço, tido como pai da psicologia moderna e inspirador de Fröbel e Herbart. Seu nome está vinculado a movimentos de reforma da educação do século XIX. Seus ensinamentos e método de ensino se estabeleceram na obra de 1801, Comment Gertrude instruit ses enfants (Como Gertrude instrui seus filhos) (SOËTARD, 2010).

${ }^{26}$ Sobre Manuel Ribeiro de Almeida Júnior, sabe-se que nasceu na cidade de Maricá (RJ) e era filho de um importante fazendeiro. Exerceu o cargo de chefe de seção da Secretaria da Instrucção Pública do Estado de São Paulo (BLAKE, 1970) e foi autor de compêndios, entre eles o Syllabario ou primeiro livro de leitura, premiado pelo Governo Imperial. Para o ensino de Matemática escreveu o Compendio de systema métrico decimal de pesos e medidas para uso das escolas e o Curso elementar de arithmetica e de calculo mental, para uso das escolas (BLAKE, 1970).
} 
publicado no periódico A instrucção pública.

Para Ribeiro de Almeida, a Aritmética era, "sem contestação, um dos ramos mais importantes do ensino primário, não só em razão de sua utilidade prática, como ainda pelos recursos que oferece para exercitar o juízo e cultivar a inteligência" (RIBEIRO DE ALMEIDA, 1872b, p.58) e aquele "em que se tem tirado mais vantagem dos princípios de Pestalozzi" (ibidem).

No artigo, o autor defendeu métodos mais ativos para o ensino, com incentivo ao uso da intuição:

O conhecimento dos números é uma sciencia necessariamente abstracta. Como, porém, as abstracções não estão ao alcance da intelligência das crianças, o meio mais natural e mais fecundo para dar-lhes idea clara do valor dos numeros, e explicar-lhes suas combinações, é a intuição. Parte-se da unidade concreta. O menino aprende a contar por objectos reaes (pontos, traços, espheras etc.). Da mesma sorte adquire as primeiras noções do calculo, sommando, subthrahindo, multiplicando e dividindo as unidades assim representadas; e para que abstraia pouco a pouco a noção pura dos numeros dos objectos visíveis deve o professor varial-os em todos os exercicios (RIBEIRO DE ALMEIDA, 1872b, p. 58).

Em outro ponto do texto, o autor criticou o ensino baseado na memória e na repetição, como ocorria no ensino mútuo:

Saber de cór não é saber. A memoria não deve ser considerada senão como auxiliar, auxiliar importante sem duvida, mas é erro suppor que a instrucção póde basear-se sobe esta faculdade do espirito (RIBEIRO DE ALMEIDA, 1872b, p. 59).

O método intuitivo ainda valorizava o saber vinculado a resultados práticos e concretos, ponto também citado por Ribeiro de Almeida:

O lado prático da arithmetica deve predominar tanto mais quanto o alumno aproxima-se do termo de seus estudos: por quanto, a escola primaria não deve ensinar somente a calcular bem, deve tambem iniciar o menino nas questões da vida pratica (RIBEIRO DE ALMEIDA, 1872b, p. 59).

$\mathrm{O}$ autor referiu-se ainda à necessidade de respeitar o amadurecimento do aluno durante o seu aprendizado. O ensino devia adequar-se à capacidade do aluno em cada fase de seu desenvolvimento, baseando-se nos sentidos.

Quando se tem de ensinar a crianças, convém seguir a marcha natural do desenvolvimento das faculdades. $O$ espirito caminha do conhecido para o desconhecido, apoiando-se no que sabe para chegar ao que ainda não sabe. Mórmente nas sciencias exactas, em que todos os princípios formam uma cadeia progressiva, não se pode supor conhecimentos que o menino não tem, e ensinar hoje o que deve ser ensinado amanhã. Ajudai a criança a sahir gradualmente do sonno descuidoso da vida instinctiva, esclarecei o despertar de suas faculdades, e guiai o primeiro exercício de sua inteligência [...]. Não ha de exigir da inteligência rápidos progressos, seria preciso desconhecer as leis da natureza; ella, como a planta, desenvolve-se insensível e progressivamente, o ensino deve ser também lento e progressivo (RIBEIRO DE ALMEIDA, 1872b, p. 59-60).

Considerações sobre o assunto já haviam sido feitas pelo autor em outro texto 
publicado no mesmo periódico:

Para que o ensino possa ser profícuo, deve exercitar todas as faculdades intellectuaes segundo a ordem do seu desenvolvimento, partindo do conhecido para o desconhecido, do facil para o difficil, do concreto para o abstracto, graduando successivamente os exercícios e as idéas sem deixar uma só em falso, levando finalmente o raciocínio da creança a caminhar pela força do próprio impulso, de modo que a escola seja uma verdadeira gymnastica da inteligência (RIBEIRO DE ALMEIDA, 1872a, p. 26).

Como lembra Schelbauer (2007), o ensino intuitivo "desembarcou na sociedade brasileira na bagagem de nossos intelectuais que aqui chegavam" (p. 10). Assim, ao menos no caso do Rio de Janeiro, mesmo antes da tradução de Rui Barbosa do manual de Calkins, essas ideias chegaram a um público mais amplo de professores por meio da imprensa e o método, de uma forma ou de outra, já estava presente nas escolas inspecionadas em 1873.

O que se percebe é que, a partir de 1870, as ideias sobre o método intuitivo que começaram a circular no Brasil enfatizaram e reconheceram a utilidade do cálculo mental, "desde que praticado sem o caráter abstrato, mas mediante problemas de aplicação usual e próximos da vida das crianças" (SOUZA, 2000, p. 19), e, em vários momentos, associado a uma ideia de modernidade em termos do ensino da aritmética.

\section{Livros didáticos para o ensino do cálculo mental}

Em relação a livros didáticos, é possível encontrar no período do Império algumas publicações que incorporaram o cálculo mental no ensino da aritmética.

Uma referência importante é o livro Guia Pedagógico de calculo mental e uso do contador mecânico ou arithmometro no ensino elementar da arithmetica. Publicado pela Livraria Clássica em $1887^{27}$ e escrita pelo autor Brazilicus, pseudônimo usado por José Carlos de Alambary Luz ${ }^{28}$, a obra se propunha a "apresentar, ensinar e convencer os futuros mestres da superioridade do cálculo mental em relação aos demais métodos de ensino utilizados na aritmética" (TEIXEIRA, 2014, p. 617).

Em seu prefácio, o livro traz uma explicação clara do que se entendia por cálculo mental na época, bem como as vantagens atribuídas a ele. Segundo o autor, o cálculo pode ser mental ou escrito; "o calculo mental, chamado também oral e pelo vulgo conta de cabeça,

\footnotetext{
${ }^{27}$ O exemplar consultado faz parte do acervo da Biblioteca Nacional, no Rio de Janeiro.

28 Segundo Blake (1970), Alambary Luz era natural de São Paulo (SP), bacharel em "sciencias sociaes e jurídicas" formado em 1853. Foi diretor do jornal A Instrucção Pública (1872-1875/1887-1888) e diretor da Escola Normal de Niterói (Estado do Rio de Janeiro) de 1868 a 1876. É Blake (1970) que indica que a obra foi traduzida e adaptada por Alambary Luz.
} 
deve preceder sempre o escripto" (LUZ, 1877, p. v). Recomenda-se "um quarto ou meia hora de lição diária, continuada por um anno” (LUZ, 1877, p. vii).

As vantagens do "contar de cabeça ou calcular mentalmente" são enumeradas a seguir:

$1^{\text {a }} \mathrm{O}$ contar mentalmente facilita muitíssimo o calcular por algarismos. Por aquelle meio adquirem as crianças idéas mais claras e evidentes dos números e tornam-se aptas para julgar qual seja a operação arithmética adequada a resolver uma questão dada. Isto por certo menos difficil e mais intelligivel torna-lhes o contar por algarismos.

$2^{\mathrm{a}}$ Faz-lhes proceder mais desembaraçadamente, sem necessidade de aprestos nem de utensílios de escripta; pelo que vê-se que póde ser aplicado simultaneamente com os trabalhos manuaes e até nas occasiões de recreio nas escolas.

$3^{a}$ É de uso frequentemente na vida commum. Acontece quasi sempre vermo-nos obrigados a contar de cabeça, sem termos tempo ou não ser caso de procurarmos uma penna ou um lapis, não há homem ou criança que não tenha tido muitas vezes occasião de reconhecer esta verdade; além de que uma enfermidade qualquer póde infelizmente determinar o uso exclusivo da arithmetica mental.

$4^{\mathrm{a}}$ É mais agradável ás crianças do que o processo graphico, e convence-as desde cedo da utilidade real da arithmetica, offerecendo-lhes freqüentes occasiões de pensar, uma vez que o preceptor saiba ensinar bem.

$5^{\text {a }}$ É o melhor meio de estimular a intelligencia e fortificar tanto o juízo como a memória dos alumnos.

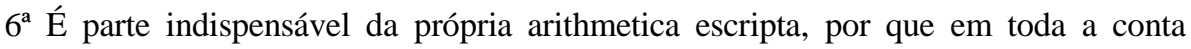
representada por algarismos somos forçados a executar de cabeça varias operações que fazem parte della, a não querermos trabalho por uma eternidade (LUZ, 1877, p. v-vi).

Mais adiante, o autor explica em que consiste um "arithmometro simples" ou "contador mecânico" que "[...] pode ser feito facilmente por qualquer curioso".

Este instrumento [...] consiste em um quadro com dez varetas horisontaes de arame ou ferro (de 5 milimetros de diâmetro), em cada uma das quaes são enfiadas dez bolas ou esferas de madeira, ou qualquer outro materia (de 5 a 8 milimetros de diâmetro), de sorte que possam folgadamente correr de uma a outra extremidade. As varetas devem ser mais compridas do que o espaço ocupado pelas espheras, para que se possam executar varias combinações em cada uma das mesmas varetas, e além disso contenham mais a taboinha móvel estreita A,B, ou C, que lhe deve ser adaptada conforme fôr necessário ao ensino (LUZ, 1877, p. 12).

A seguir tem-se uma imagem do objeto descrito.

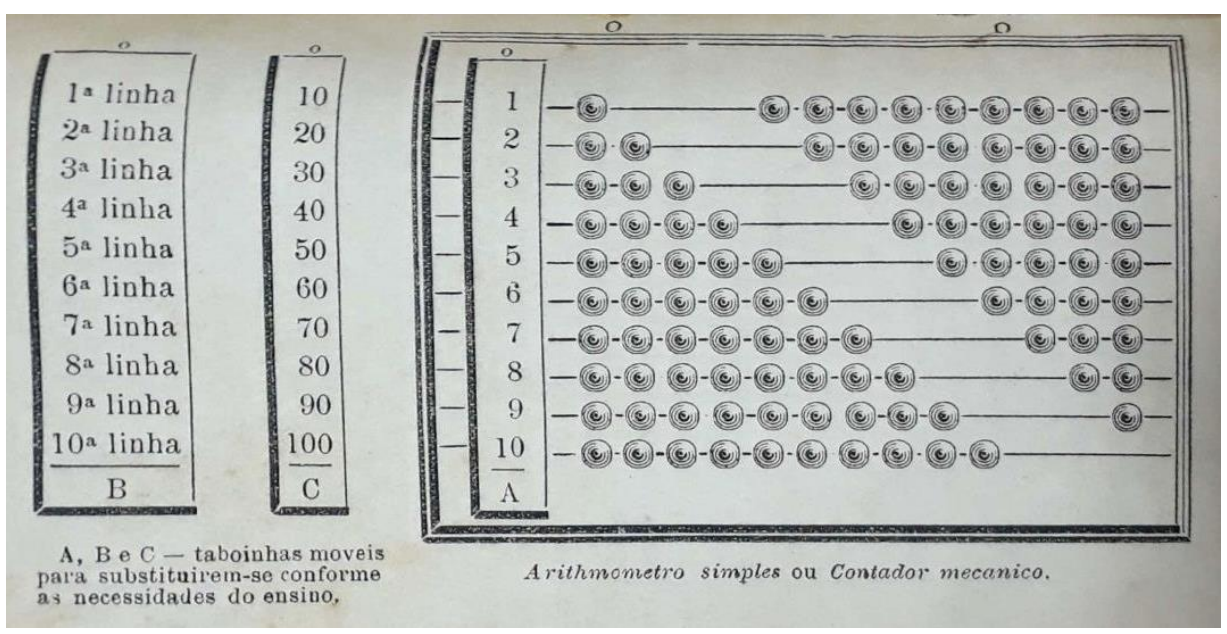

Figura 5 - Desenho de um aritmômetro simples ou contador mecânico Fonte: LUZ (1877, p. 14)

Outra referência é o livro de Ribeiro de Almeida, Curso elementar de arithmetica e do 
cálculo mental $^{29}$, de 1880. Um parecer da obra, publicado em 1881 no jornal $O$ apóstolo ${ }^{30}$, relacionava mais uma vez o cálculo mental à ideia de modernização do ensino e como prática já adotada em países mais adiantados.

Os capítulos relativos ao calculo mental e à resolução de problemas pela redução à unidade constituem certamente um grande melhoramento introduzido pelo autor no ensino da arithmetica elementar, melhoramento conhecido nos paizes mais adiantados em instrucção publica, mas entre nós em completo esquecimento $(\mathrm{O}$ APÓSTOLO, 1881, p. 2).

Segundo o parecer, na introdução da obra o autor fazia críticas ao sistema de ensino usado nas escolas, "já condenado em todo o mundo civilizado" (idem, p.1), e apresentava o método intuitivo como "o mais racional e fecundo, para dar às crianças uma idéa clara dos números e de suas combinações" (ibidem). O livro apresentava-se como material útil também aos professores, que "terão um poderoso meio para desenvolver na infância a intelligência e a memoria dos numeros" (idem, p. 2).

O parecer lamentava que o ensino do cálculo mental "não se acha ainda introduzido em nossas escolas" (ibidem) e relacionava essa ausência à falta de livros próprios, que seria corrigida com livros como o de Ribeiro de Almeida.

Foram feitas consultas a livros publicados no século XIX e utilizados nas escolas brasileiras, como: Explicador de Arithmetica, de Eduardo de Sá Pereira de Castro; Elementos de Arithmetica, de Christiano Benedicto Ottoni; Noções de Arithmetica Elementar, de J. B. de Azevedo Coimbra; Arithmetica Elementar, de B. Alves Carneiro; Primeiras Noções de Arithmetica para uso das Escholas de Ensino Primário, de Ayres de Vasconcelos Cardoso Homem; Postilas de Arithmetica para meninos, de Victor Renault. Nessas obras não foram encontradas referências ao cálculo mental. Em outros livros analisados por Costa (2000), além do livro de Alambary Luz citado neste texto, também não há menção ao cálculo mental.

\section{0 cálculo mental na legislação de ensino}

Na legislação, o ensino pelo método intuitivo é destacado, de forma explícita, somente no ano de 1879, com a Reforma de Leôncio de Carvalho ${ }^{31}$. As "Noções de cousas" e os

\footnotetext{
${ }^{29}$ Não foi localizado nenhum exemplar desse livro para consulta.

${ }^{30}$ O Apóstolo, 25 de março de 1881. Disponível na Hemeroteca Digital Brasileira, da Biblioteca Nacional, em: http://memoria.bn.br/hdb/periodo.aspx.

31 Carlos Leôncio de Carvalho, por meio do Decreto de 19 de abril de 1879, reformou a instrução pública primária e secundária no Município da Corte e o Ensino Superior em todo o Império dando liberdade para a criação de escolas primárias e secundárias, inclusive particulares. A legislação ainda previa a obrigatoriedade do
} 
"Princípios elementares de aritmética" estavam previstos como disciplinas nas escolas primárias de $1^{\circ}$ grau (BRASIL, 1880, Art. 4) e a "Prática do ensino intuitivo ou lições de cousas" constava como disciplina também para as Escolas Normais ${ }^{32}$ do País (BRASIL, 1880, Art. 9), além do ensino de "Aritmética, álgebra e geometria". O decreto, entretanto, não fazia menção direta a conteúdos que deveriam ser abordados nem especialmente ao cálculo mental.

O cálculo mental, ao que parece, consta na legislação brasileira somente na década de 1880. Para a escola primária, o cálculo mental estava presente no Regimento Interno para as Escolas Públicas Primárias do $1^{o}$ grau do Município da Corte, aprovado em $1883^{33}$ para começar a vigorar a partir de janeiro de 1884.

$\mathrm{Na}$ escola pública primária do $1^{\circ}$ grau, era ensinada a instrução moral e religiosa; leitura; escrita; noções essenciais de gramática; princípios elementares de aritmética; sistema métrico decimal; noções de história e geografia do Brasil; elementos de desenho linear; rudimentos de música e exercícios de ginástica (BRASIL, 1884, Art. 1). Os alunos deveriam ser divididos em três classes, conforme aproveitamento: na $1^{a}$ classe, ou elementar, os que não soubessem ler; na $2^{\mathrm{a}}$, ou de transição, os que principiassem a ler com desembaraço; e na $3^{\mathrm{a}}$ classe, ou superior, os que fossem capazes de leitura corrente (BRASIL, 1884, Art. 37). Para cada classe havia instruções detalhadas quanto ao aprendizado da aritmética e do sistema de pesos e medidas.

No regimento, era reforçado o uso do contador mecânico, que devia ser usado como base dos exercícios de numeração, objeto de ensino da $1^{\mathrm{a}}$ classe, e, mais adiante, para a prática do cálculo mental.

\begin{abstract}
O contador mecânico servirá de base exclusiva aos exercícios de numeração, os quais serão graduados ao aproveitamento da classe. Os alunos mais adiantados assistirão aos exercícios dos companheiros. Começará o professor pela formação dos números até 10, e para cada turma exigirá depois a combinação dos números até 100 , até 1.000 e seguintes, à proporção que os alunos se mostrarem conhecedores dos precedentes. Nenhum aluno passará a aprender a formação dos números além de 10 antes de conhecer praticamente a teoria das quatro operações fundamentais, aplicadas a esses números, com auxílio sempre do contador mecânico. Da mesma forma se procederá na passagem da numeração depois de 100, e assim por diante. Os exercícios de escrita dos números no quadro preto acompanharão progressivamente o ensino da formação dos mesmos (BRASIL, 1884, Art. 46, § $4^{\circ}$ ).
\end{abstract}

Para os alunos da $2^{\mathrm{a}}$ classe, o regimento recomendava ao professor que:

ensino dos 7 aos 14 anos de idade para ambos os sexos, a criação de jardins de infância, bibliotecas e museus escolares.

${ }^{32}$ As Escolas Normais no Brasil foram criadas como cursos para a formação do magistério primário. A primeira delas foi fundada na província do Rio de Janeiro, na cidade de Niterói, em 1835. Outras escolas foram sendo criadas nas demais províncias, ao longo do Império, como na Bahia, em 1836; em Minas Gerais, em 1840 e em São Paulo, no ano de 1863. Na Corte, foi instalada em 1880.

${ }^{33}$ Decisão n. 77 de 06 de novembro de 1883. Ver Castanha (2013). 
diariamente exercite os alunos no cálculo mental, subindo dos números simples aos mais compostos. O cálculo mental versará sobre a formação de números e sobre resolução de problemas simples acerca de quantidades concretas. Estes problemas consistirão em pequenas questões da vida comum e da doméstica, e, sempre que for possível, o professor os preparará com relação ao dispêndio determinado por certos hábitos viciosos ${ }^{34}$; as bebidas, o tabaco, o luxo etc. (BRASIL, 1884, Art. 47, $\S 4^{\circ}$ ).

O cálculo mental também estava presente no ensino do sistema métrico decimal para a $2^{\mathrm{a}}$ classe:

O sistema métrico decimal continuará a ser ensinado pelo método intuitivo. Os alunos aprenderão a conhecer de modo concreto os múltiplos e submúltiplos de cada unidade. Servir-se-ão deles materialmente na aula e procurarão determinar as relações entre os múltiplos e submúltiplos por meio do cálculo mental (BRASIL, 1884 , Art. $47, \S 5^{\circ}$ ).

$\mathrm{Na} 3^{\mathrm{a}}$ classe, o estudo avançava e propunham-se exercícios mentais, além do entendimento do conteúdo e sua aplicação por meio de problemas.

O cálculo consistirá no aperfeiçoamento dos exercícios mentais e na prática das quatro operações sobre inteiros, frações ordinárias e decimais. O professor evitará cuidadosamente que os alunos decorem as regras de qualquer compêndio; deverá antes obrigá-los a explicar com palavras suas os mecanismos das operações que efetuarem, quando nelas estiverem práticos. O ensino do sistema métrico abrangerá a resolução de problemas sobre o emprego dos pesos e medidas e explicações teóricas sobre os mesmos (BRASIL, 1884, Art. 48, § $4^{\circ}$ ).

Em seu Relatório do ano de 1883, o ministro do Império Francisco Antunes Maciel reiterou seus esforços para "ampliar-se o mais possível o ensino pelo methodo intuitivo, cujas vantagens são incontestáveis" (BRASIL, 1884, p. 53), dotando as escolas de objetos necessários para tal. Em novembro de 1883, o ministro autorizou a despesa de 8.000 francos com a compra de "100 arithmometros de Arens para auxiliar o ensino do calculo e da metrologia por aquelle processo" (ibidem). Os materiais, encomendados da Europa, chegaram às escolas em junho de 1884.

Anos mais tarde, em 1888, o ministro do Império Antonio Ferreira Vianna ainda via como crítica a situação do ensino e disse estar convencido de que era preciso regenerar o ensino primário no Império, "formando professores com a necessária instrucção scientifica profissional" (BRASIL, 1889, p. 13). Além disso, disse ser indispensável que o Governo concedesse os recursos para a organização das públicas de todo o Império, facilitando às províncias a aquisição de mestres mais habilitados.

Assim, a fim de "assegurar ás novas gerações a indispensável educação physica, moral e intelectual, racionalmente ministrada" (BRASIL, 1889, p. 12), o Decreto n. 10.060, de 13 de

\footnotetext{
${ }^{34}$ Elas serviriam como base para discutir os valores morais com as crianças (CASTANHA, 2013, p. 286).
} 
outubro de 1888, estabeleceu um novo regulamento para a Escola Normal da Corte ${ }^{35}$, e em 1 de dezembro foi expedido o programa de ensino como previsto ${ }^{36}$ nos Artigos 111 e 132.

De acordo com o programa, o estudo das Mathematicas Elementares, em seu primeiro ano de curso, era composto por aulas de aritmética e geometria plana e, para os meninos, noções de escrituração mercantil. Dentre os primeiros tópicos da aritmética, junto às operações fundamentais sobre números inteiros, os estudantes trabalhavam "Problemas variados sobre as quatro operações, isoladas e combinadas. - Processos rápidos de calculo mental e escripto" (BRASIL, 1889, Anexo C, p. 46). O Decreto não menciona métodos de ensino a serem seguidos, mas explicita que o curso tem por fim exercitar os alunosprofessores "na maneira natural do dar o ensino educando-os na methodologia propria de cada disciplina" (BRASIL, 1889, Anexo C, Art. 115, p. 23).

No que se refere ao ensino secundário, o Colégio Pedro $\mathrm{II}^{37}$, fundado em 1837, destacou-se durante todo o período do Império como o estabelecimento de referência nesse nível no Brasil ${ }^{38}$ e a partir do qual "a própria denominação de ensino secundário passa a ter curso legal entre nós" (MENDONÇA et al, 2013, p. 987). A primeira matriz curricular do Colégio foi determinada em 1838 e as matérias ensinadas foram distribuídas inicialmente em oito séries, alteradas depois para sete. O programa apresentava uma extensão enciclopédica na qual predominavam os estudos clássicos humanistas, mas com a presença da matemática, das ciências naturais e físicas, da história e das línguas modernas.

\footnotetext{
$35 \mathrm{O}$ Artigo 108 descreve todas as matérias a serem ensinadas na instituição: "O ensino comprehende as seguintes materias: religião. instruç̧ão moral e civica e noções de economia politica. Pedagogia e legislação escolar. Portuguez e noções de historia da litteratura, da lingua vernacula. Francez. Geographia e particularmente a do Brazil. Historia e particularmente a do Brazil até nossos dias. Arithmetica e algebra elementar. Noções de escripturação mercantil, sómente para os alumnos. Geometria. Elementos de physica; chimica; botanica; zoologia e geologia, com as suas principaes applicações. Escripta. Desenho. Musica vocal. Trabalhos manuaes para os alumnos; trabalhos de agulha para as alumnas. Gymnastica, e, para os alumnos, exercicios militares" (BRASIL, 1889, Anexo C, p. 21).

36 O Programa de Ensino para a Escola Normal da Corte consta no Anexo C do Relatório do Ministro do Império para o ano de 1888 .

${ }^{37}$ O Colégio Pedro II, na cidade do Rio de Janeiro, foi a primeira escola secundária pública do Brasil. Foi criado nos moldes da escola francesa e era voltado para a formação da elite brasileira. O Colégio oferecia o curso de "bacharelado em letras", que dava ao aluno direito ao ingresso em cursos de nível superior, Medicina e Direito, sem a necessidade de novos exames. Atualmente o Colégio possui unidades no Centro da cidade (a primeira a ser criada) e em vários bairros do Rio de Janeiro, além de outras nas cidades de Niterói e Duque de Caxias. A instituição pertence à rede federal de ensino brasileira.

${ }^{38}$ O Colégio Pedro II se manteve como estabelecimento padrão de ensino secundário no Brasil não somente no período do Império, mas também em durante boa parte do século $\mathrm{XX}$, influenciando várias reformas de ensino durante o período republicano.
} 
A aritmética fazia parte do programa de ensino referente à área de Matemática, sendo que esta estava presente ao longo dos sete anos do curso secundário. Em seus programas, ao final do século XIX ${ }^{39}$, o “cálculo mental” figurava como conteúdo a ser ensinado.

Em 1881, o ministro do Império, Barão Homem de Mello, alterou os regulamentos do Colégio Pedro II. No programa de ensino de aritmética prática para o primeiro ano do curso, havia menção explícita a exercícios de cálculo mental. Segundo o Decreto n. 8.051, de 24 de março de 1881, o ensino de aritmética devia abranger:

Calculo dos números inteiros e de fracções; problemas. - Exercícios de cálculo mental. - Prática do systema métrico decimal. Reducção de pesos e medidas à unidade principal. Comparação dos pesos e medidas actuaes com os outr'ora em uso. Exercícios de conversão dos pesos e medidas de um systema nos de outro (BRASIL, 1882, Art. 3).

O compêndio recomendado era a terceira edição de Noções de Arithmetica, por Manoel Olympio Rodrigues da $\operatorname{Costa}^{40}$.

Na última década do século XIX, o Decreto n. 981, de 8 de novembro de 1890, mais conhecido como Reforma Benjamin Constant, aprovou novo regulamento para a instrução primária e secundária para as escolas da cidade do Rio de Janeiro, agora Distrito Federal.

As escolas primárias foram organizadas em escolas primárias do $1^{\circ}$ grau (com seis anos) e escolas primarias do $2^{\circ}$ grau (com três anos). As escolas de $1^{\circ}$ grau dividiam-se em três cursos: o elementar (para alunos de 7 a 9 anos), o médio (para os de 9 a 11) e o superior (para os de 11 a 13), sendo gradualmente feito em cada curso o estudo de todas as matérias. O certificado de conclusão da escola de $1^{\circ}$ grau garantia a entrada nos estabelecimentos de ensino secundário e normal, enquanto o certificado de conclusão da escola de $2^{\circ}$ grau, além desse direito, dava isenção em alguns exames aos candidatos a empregos administrativos, que não exigiam habilitação técnica especial.

Nas escolas de $1^{\circ}$ grau ensinava-se: "Contar e calcular. Arithmetica pratica até regra de tres, mediante o emprego, primeiro dos processos espontaneos e depois dos processos systematicos" (BRASIL, 1890, Art. 3) ${ }^{41}$. O cálculo mental está presente de modo explícito no

\footnotetext{
39 Os programas de Matemática do Colégio Pedro II podem ser consultados em Beltrame (2000). Ver também Vechia; Lorenz (1998).

${ }^{40}$ Manoel Olympio Rodrigues da Costa era natural da Bahia e de 1874 a 1878 figurou no quadro docente do Colégio como professor de português, aritmética e geografia e na Escola Normal da Corte. De sua autoria consta, em Blake (1970), a Grammatica portuguesa, destinada aos alunos do primeiro ano do Colégio Pedro II, com terceira edição de 1887; Noções de arithmetica e do systema métrico decimal para uso das escolas, obra aprovada e adotada pelo governo imperial no Colégio Pedro II e nas aulas públicas do Rio de Janeiro. Faleceu em 1891.

${ }^{41}$ Para as escolas primárias de $1^{\circ}$ grau além da aritmética, já destacada, ensinava-se "Leitura e escripta; ensino pratico da lingua portugueza; contar e calcular. Arithmetica pratica até regra de tres, mediante o emprego, primeiro dos processos espontaneos, e depois dos processos systematicos; systema metrico precedido do estudo
} 
ensino de aritmética em todos os anos da escola de $1^{\circ}$ grau, como se pode ler no detalhamento do programa ao final do texto do Decreto:

\section{Curso elementar}

CLASSE $1^{\mathrm{a}}$

Arithmetica - Contar, primeiramente pelos processos espontaneos, empregando os dedos, riscas, pedrinhas (calculos), grãos, contas etc, e depois os rosarios, o contador mecanico, o crivo numeral e os abacus, usada entretanto a terminologia propria da nomenclatura systematica. Conhecimento pratico das unidades fraccionarias: metade, terça parte, quarta parte etc, e comparação dessas unidades entre si. Escrever os algarismos. Exercicios praticos de sommar, diminuir e multiplicar os numeros simples. Exercicio mental de problemas faceis. Conhecimento pratico do metro e sua divisão em decimos e centesimos. Ler e escrever qualquer numero de tres algarismos. Conhecimento pratico da moeda-papel até ás notas de $100 \$ 000$.

CLASSE $2^{\mathrm{a}}$

Arithmetica - Ler e escrever numeros compostos até seis algarismos, empregando os processos primitivos e o systematico. Idéa clara da unidade, dezena e centena de milhar. Valor das maiusculas usadas como algarismos romanos. Exercicios das quatro operações, sempre sob o ponto de vista concreto. Calculo mental. Termos da fracção e sua significação. Ler e escrever fracções decimaes até cinco algarismos. Da semana; do mez; do anno; do dia em horas e minutos. Conhecimento pratico das moedas nacionaes. Medidas metricas.

Curso médio

CLASSE $1^{\mathrm{a}}$

Arithmetica - Revisão do programma anterior. Ler e escrever numeros compostos de mais de seis algarismos. Systema de numeração romana. Conhecimento do quadrado, cubo, raiz quadrada e raiz cubica. Systema-metrico completo. Conhecimento pratico das principaes moedas estrangeiras. Problemas concretos. Calculo mental.

\section{CLASSE $2^{\mathrm{a}}$}

Arithmetica - Revisão do programma anterior. Propriedades das fracções ordinarias e decimaes. Problemas. Calculo mental.

Curso superior

CLASSE $1^{\mathrm{a}}$

Arithmetica - Revisão da materia estudada; operações sobre as fracções ordinarias e decimaes. Numeros primos; crivo de Eratosthenes. Principaes caracteres da divisibilidade dos numeros escriptos no systema decimal. Principios da decomposição dos numeros em seus factores primos. Maximo commum divisor, empregando em primeiro lugar as linhas rectas. Problemas. Calculo mental.

CLASSE $2^{\mathrm{a}}$

Arithmetica - Noções sobre os numeros complexos e suas operações. Regra de tres e suas applicações, pelo methodo de reducção á unidade. Revisão geral. Problemas. Calculo mental. Noções de escripturação mercantil (BRASIL, 1890, grifos nossos).

Percebe-se que o cálculo mental na Reforma Benjamin Constant estava associado a "problemas concretos". Para Pais (2015), o destaque de aspectos práticos no ensino dos

da geometria pratica (tachymetria); elementos de geographia e historia, especialmente do Brazil; lições de cousas e noções concretas de sciencias physicas e historia natural; instrucção moral e civica; desenho; elementos de musica; gymnastica e exercicios militares; trabalhos manuaes (para os meninos); trabalhos de agulha (para as meninas); noções praticas de agronomia". Nas escolas primarias do $2^{\circ}$ grau ensinava-se: "Calligraphia; portuguez; elementos de lingua franceza; arithmetica (estudo complementar). Algebra elementar. Geometria e trigonometria; Geographia e historia, particularmente do Brazil; elementos de sciencias physicas e historia natural applicaveis ás industrias, á agricultura e á hygiene; noções de direito patrio e de economia politica; desenho de ornato, de paisagem, figurado e topographico; musica; gymnastica e exercicios militares; trabalhos manuaes (para os meninos) e trabalhos de agulha (para as meninas)” (BRASIL, 1890, Art. 4). 
números e a precedência dos processos espontâneos em relação aos formais visava inculcar uma cultura escolar de natureza mais pragmática do que aquela que predominava nas práticas anteriores. Pelo Decreto, em todos os anos da escola primária de $1^{\circ}$ grau estava previsto o emprego do método intuitivo e o livro seria um simples auxiliar. Na visão do autor, essas orientações pretendiam acompanhar o movimento de modernização pedagógica da época e tinham intenção de superar as antigas práticas do século XIX, concebidas com ênfase na memorização, na repetição e na retórica. Pais (2015) observa que o método intuitivo ainda era desconhecido pelos professores e prevaleciam livros didáticos escritos em sintonia com as práticas até então predominantes. A essa época nota-se, por exemplo, a presença do livro de Alambary Luz nos anúncios da Livraria Clássica em vários jornais cariocas até os últimos anos do século XIX.

\section{Considerações finais}

Neste texto buscou-se destacar de que forma o cálculo mental esteve presente em escolas na cidade do Rio de Janeiro durante o século XIX. Pelas informações que localizamos, percebeu-se que a expressão já era conhecida pelos professores e fazia parte de sua prática pedagógica antes mesmo de ser prescrita oficialmente pela legislação de ensino. Esta, por sua vez, previa o abastecimento das escolas com equipamentos como o "contador mecânico", mas também suscitou ações quanto à formação dos professores com a divulgação e a inclusão do cálculo mental como tópico a ser ensinado nas Escolas Normais.

Além disso, a publicação de obras didáticas e manifestações na imprensa deram destaque ao método que ajudaria "nas questões práticas do dia a dia e que contribuiriam para o estímulo do desenvolvimento da inteligência, em detrimento ao uso da memória, considerado por muitos como algo atrasado" (TEIXEIRA, 2014, p. 622).

Associado a ideias do método intuitivo ou não, o cálculo mental constituiu-se como elemento considerado importante para educadores e legisladores e esteve presente em instituições escolares brasileiras de diversos níveis de ensino desde a década de 1860 e continuou sendo indicado em programas de ensino durante o período republicano ${ }^{42}$.

42 Até o fim do século, o cálculo mental não estava presente em todos os anos de estudo do ensino secundário, por exemplo, mas voltou a fazer parte dos programas do Colégio Pedro II para os anos de 1899, 1900 e 1901 , atestando uma preocupação calcada em sua utilidade prática (GOMES, 2007). O cálculo mental aparece no programa de ensino para o ano de 1899, nas instruções para o ensino da Matemática aprovado pelo Decreto $\mathrm{n}$. 3.251, de 8 de abril, que se repete no programa de 1901 . 
Em suas conclusões, Gomes (2007) ressalta que, mesmo hoje em dia, há certo preconceito com a prática do cálculo mental e, apesar de presente em orientações para os professores em programas e livros didáticos, continua a ser pouco valorizada. Ao lado de outras formas de cálculo (o escrito, com a calculadora), certamente o cálculo mental se constitui em artifício importante no dia a dia de todos, e sua presença na escola básica deveria ser revista a fim de que possa ser incorporada de forma eficiente para o aprendizado da Matemática em vários conteúdos.

\section{Referências}

ALFONSO, B. G. La enseñanza del cálculo mental. Unión - Revista Iberoamericana de Educación Matemática, San Cristóbal de La Laguna, n. 4, p. 17-29, dez. 2005. Disponível em: <www.fisem.org. br>. Acesso em: 13 abr. 2007.

BASTOS, M. H. C. O ensino mútuo no Brasil (1808-1827). In: BASTOS, M. H. C.; FARIA FILHO, L. (Orgs.). A escola elementar no século XIX: o método monitorial/mútuo. Passo Fundo: Ediupf, 1999. p. $95-118$.

BASTOS, M. H. C. Educação Infantil e ensino intuitivo: a contribuição de Marie Pape-Carpantier (1815-1878). Conjectura, Caxias do Sul, v. 15, n. 3, p. 14-46, set./dez. 2010.

BELTRAME, J. Os programas de ensino de matemática do Colégio Pedro II: 1837-1932. 2000. 259 f. Dissertação (Mestrado em Matemática) - Departamento de Matemática, Pontifícia Universidade Católica do Rio de Janeiro, Rio de Janeiro, 2000.

BLAKE, A. V. A. S. Diccionario Bibliographico Brazileiro. Rio de Janeiro: Conselho Federal de Cultura, 1970. Disponível em: <https://digital.bbm.usp.br/handle/bbm-ext/22>. Acesso em: 15 mar. 2013.

BRASIL. Secretaria de Educação Fundamental. Parâmetros Curriculares Nacionais: Matemática. Secretaria de Educação Fundamental. Brasília: MEC/SEF, 1997.

CASTANHA, A. P. Edição crítica da legislação educacional primária do Brasil imperial: a legislação geral e complementar referente à Corte entre 1827 e 1889. Francisco Beltrão: Unioeste; Campinas: Navegando Publicações, 2013.

CORTÉS, F. J. Análisis de las estrategias de cálculo estimativo que utilizan estudiantes de $2^{\circ}$ de secundaria en Baja California. 2001. 109f. Tesis (Maestría en Ciencias Educativas) - UABC, Ensenada, México, 2001.

COSTA, D. A. As concepções e contribuições de Pestalozzi, Grube, Parker e Dewey para o ensino da aritmética no nível elementar: o conceito de número. Hist. Educ., Porto Alegre, v. 18, n. 42, p. 37-59, jan./abr. 2014.

COSTA, G. M. L. Os livros didáticos de matemática no Brasil do século XIX. 2000. 108f. Dissertação (Mestrado em Matemática) - Departamento de Matemática, Pontifícia Universidade Católica do Rio de Janeiro, Rio de Janeiro, 2000. 
FARIA FILHO, L. M.; VIDAL, D. G. Os tempos e os espaços escolares no processo de institucionalização da escola primária no Brasil. Revista Brasileira de Educação, Rio de janeiro, n. 14, p. 19-34, mai./ago. 2000.

FRIDMAN, F. Cartografia fluminense no Brasil Imperial. In: SIMPÓSIO BRASILEIRO DE CARTOGRAFIA HISTÓRICA, 1., 2011, Paraty. Anais... Belo Horizonte: Centro de Referência em Cartografia Histórica, 2011. p. 1-22.

GOMES, M. L. M. O cálculo mental na história da matemática escolar brasileira. In: ENCONTRO NACIONAL DE EDUCAÇÃO MATEMÁTICA, 9., 2007, Belo Horizonte. Anais... Recife: Sociedade Brasileira de Educação Matemática, 2007. p. 1-16.

GOMES, M. L. M. Lições de coisas: apontamentos acerca da geometria no manual de Norman Allison Calkins (Brasil, final do século XIX e início do XX). Rev. Bras. Hist. Educ., Campinas, v. 11, n. 2 (26), p. 53-80, mai./ago. 2011.

GONDRA, J.; GARCIA, I.; SACRAMENTO, W. Estado imperial e educação escolar - Rediscutindo a reforma Couto Ferraz (1854). In: CONGRESSO BRASILEIRO DE HISTÓRIA DA EDUCAÇÃO, $1 .$, 2000, Rio de Janeiro. Anais... Rio de Janeiro, 2000. CD-ROM.

LUZ, J. C. A. Guia pedagógico de cálculo mental e uso do contador mecânico ou aritmômetro no ensino elementar da aritmética. Rio de Janeiro: Livraria Clássica de Alves e Cia., 1887.

MENDONÇA, A. W. P. C. et al. A criação do Colégio de Pedro II e seu impacto na constituição do magistério público secundário no Brasil. Educ. Pesqui., São Paulo, v. 39, n. 4, p. 985-1.000, out./dez. 2013.

MESQUIDA, P. O método em Pestalozzi: a matemática como caminho para a verdade. Revista de História da Educação Matemática (HISTEMAT), São Paulo, ano 2, n. 1, p. 19-39, 2016.

MIZUTA, C. M. M. Do ideal ao real: a trajetória da escola noturna de instrução primária para adultos da Sociedade Auxiliadora da Industria Nacional, 1867-1892. In: ENCONTRO DO GRUPO INTERDISCIPLINAR DE PESQUISA EM ARTES, 4.; ENCONTRO DO GRUPO DE ESTUDOS E PESQUISA EM HISTÓRIA DA EDUCAÇÃO OITOCENTISTA, 2., 2011, Curitiba. Anais... Curitiba: Faculdade de Artes do Paraná, 2011, v. 1. p. 35-42. Disponível em: <http://www.fap.pr.gov.br/arquivo s/File/COMUNICACAO_2013/Publicacoes/GIPA_e_GEPHEO/02-Do_ideal_ao_real_celina_miz uta.pdf $>$. Acesso em: 25 maio 2017.

MOACYR, P. A instrução e o Império (subsídios para a história da educação no Brasil) 1823-1853. v. 1. São Paulo: Nacional, 1936.

NCTM - National Council of Teachers of Mathematics. An Agenda for Action: recommendations for School Mathematics of the 1980's. Reston: VA-USA, 1980. Disponível em: <https://www.nctm.org /Standards-and-Positions/More-NCTM-Standards/An-Agenda-for-Action-(1980s)/ >. Acesso em: 07 mai. 2017.

OLIVEIRA, A. A. O ensino público. Brasília: Senado Federal; Conselho Editorial, 2003.

OLIVEIRA, M. C. M. O ensino da aritmética nas escolas do Paraná na primeira república. Zetetiké, Campinas, v. 19, n. 3, p. 27-49, jul./dez. 2011.

PAIS, L. C. História dos aritmômetros escolares no ensino primário da matemática no Brasil (18831927). Em Teia - Revista de Educação Matemática e Tecnológica Ibero-americana, Recife, v. 5, n. 2, p. 1-18, 2014. 
PAIS, L. C. Aspectos históricos do ensino do cálculo mental na instrução primária brasileira (1848-1910). Acta Scientiae, Canoas, v. 17, p. 113-133, 2015.

PARRA, C. Cálculo mental na escola primária. In: PARRA, Cecília; SAIZ, Irma (Orgs.). Didática da matemática: reflexões psicopedagógicas. Porto Alegre: Artes Médicas, 1996. p. 186-235.

RIBEIRO DE ALMEIDA, M. A escola. A Instrucção Pública, Rio de Janeiro, n. 4, p. 25-26, 1872a [5 de maio de 1872].

RIBEIRO DE ALMEIDA, M. A arithmetica. A Instrucção Pública, Rio de Janeiro, n. 8, p. 58-59, $1872 b$ [2 de junho de 1872].

SCHELBAUER, A. R. O método intuitivo e lições de coisas no Brasil do século XIX. In:

STEPHANOU, M.; BASTOS, M. H. C. Histórias e memórias da educação no Brasil. v. II - Século XIX. Petrópolis: Vozes, 2005. p. 132-149.

SCHELBAUER, A. R. Entre anúncios e artigos: registros do método de ensino intuitivo do jornal $A$ Província de São Paulo (1875-1889). In: SCHELBAUER, A. R.; ARAÚJO, J. C. S. (Org.) História da educação pela imprensa. Campinas: Alínea, 2007. p. 7-30.

SILVA, D. H.; MACHADO, M. C. G. O método de ensino intuitivo e a política educacional de Benjamin Constant. Revista Eletrônica de Educação, São Carlos, v. 8, n. 2, p. 198-211, 2014.

SOARES, F. dos S. O Professor de Matemática no Brasil (1759-1879): aspectos históricos. Rio de Janeiro. 2007. 172f. Tese (Doutorado em Educação) - Departamento de Educação, Pontifícia Universidade Católica do Rio de Janeiro, Rio de Janeiro, 2007.

SOËTARD, M. Johann Pestalozzi. Trad. Martha Aparecida Santana Marcondes, Pedro Marcondes, Ciriello Mazzetto. Organização: João Luis Gasparin, Martha Aparecida Santana Marcondes. Recife: Fundação Joaquim Nabuco/ Massangana, 2010. Disponível em:<http://www.dominiopublico.gov.br/ download/texto/me4681.pdf>. Acesso em: 25 mai. 2017.

SOUZA, R. F. de. Inovação educacional no século XIX: A construção do currículo da escola primária no Brasil. Cadernos Cedes, Campinas, n. 51, p. 9-28, nov. 2000.

TEIXEIRA, G. B. Os "Principios elementares da arithmetica" nas escolas da corte imperial. Cadernos de História da Educação, Campinas, v. 13, n. 2, p. 603-624, jul./dez. 2014.

VALDEMARIN, V. T. O método intuitivo: os sentidos como janelas e portas que se abrem para um mundo interpretado. In: SAVIANI, D. et al. O legado educacional do século XIX. 2. ed. Campinas: Autores Associados, 2006. p. 85-132.

VECHIA, A.; LORENZ, K. M. (Orgs.). Programa de ensino da escola secundária brasileira: 18501951. Curitiba: Ed. do Autor, 1998.

\section{Jornais}

CORREIO da Tarde, 11 de maio de 1862, página 3.

DIÁRIO do Rio de Janeiro, 01 de janeiro de 1875, página 3.

O APÓSTOLO, 25 de março de 1881, página 1-2.

O GLOBO, 8 de outubro de 1874, página 3. 


\section{Legislação}

BRASIL. Decisão n. 77 do Ministério do Império de 6 de novembro de 1883. Aprova o regimento interno para as escolas públicas primárias do $1^{\circ}$ grau do município da Corte. Coleção das Decisões do Governo do Império do Brasil de 1883. Rio de Janeiro: Typographia Nacional, 1884, p. 76-91. Disponível em: <http://www.camara.gov.br/Internet/InfDoc/Conteudo/Colecoes/Legislacao/deci soes1883/pdf9.pdf>. Acesso em: 27 mai. 2017.

BRASIL. Lei de 15 de outubro de 1827, sancionando Ato do Poder Legislativo. Manda criar escolas de primeiras letras em todas as cidades, vilas e lugares mais populosos do Império. Coleção das Leis do Império do Brasil de 1827 - Primeira parte. Rio de Janeiro: Typographia Nacional, 1878, p. 7173. Disponível em: <http://www.camara.leg.br/Internet/InfDoc/conteudo/colecoes/Legislacao/LegimpJ_19.pdf\#page $=1 \geq$. Acesso em: 27 mai. 2017.

BRASIL. Decreto n. 1331-A, de 17 de fevereiro de 1854, do Ministério do Império. Aprova o Regulamento para a reforma do ensino primário e secundário do Município da Corte. Coleção das Leis do Império do Brasil de 1854 - Tomo XVII. Parte II. Rio de Janeiro: Typographia Nacional, 1854. p. 45-69. Disponível em: <http://www.camara.gov.br/Internet/InfDoc/conteudo/colecoes/Le gislacao/1854\%20pronto/leis\%201854/dec\%20n\%b01325\%20\%e0\%201331A-pg12-p11.pdf>. Acesso em: 27 mai. 2017.

BRASIL. Decreto n. 7247, de 19 de abril de 1879, do Ministério do Império. Reforma o ensino primário e secundário no município da Corte e o superior em todo o Império. Coleção das Leis do Império do Brasil de 1879 - Parte II, Tomo XLII. Rio de Janeiro: Typographia Nacional, 1880. p. 196-217. Disponível em: <http://www.camara.leg.br/internet/infdo c/conteudo/colecoes/legislacao/legimpcd-06/leis\%201879\%20(969p)/leis1879_1033.pdf\#p age=11>. Acesso em: 27 mai. 2017.

BRASIL. Decreto n. 8.051, de 24 de março de 1881, do Ministério do Império. Altera os regulamentos do Imperial Collegio de Pedro II. Coleção das Leis do Império do Brasil de 1881 - Parte II, Tomo XLIV. Rio de Janeiro: Typographia Nacional, 1882. p. 225-238. Disponível em: <http://www2.camara.leg.br/legin/fed/decret/1824-1899/decreto-8051-24-marco-1881-546219publicacaooriginal-60154-pe.html>. Acesso em: 27 mai. 2017.

BRASIL. Decreto n. 981, de 8 de novembro de 1890. Approva o Regulamento da Instrucção Primaria e Secundaria do Districto Federal. Coleção de Leis do Brasil - 1890. Palácio do Governo Provisório: 1890, Vol. Fasc. XI. p. 3.474 [Legislação informatizada]. Disponível em: <http://www2.camara.leg.br /legin/fed/decret/1824-1899/decreto-981-8-novembro-1890-515376-publicacaooriginal-1-pe.html>. Acesso em: 27 mai. 2017.

BRASIL. Relatório do ano de 1870 do Ministro dos Negócios do Império, João Alfredo Corrêa de Oliveira. Apresentado à Assembleia Geral Legislativa na $3^{\mathrm{a}}$ sessão da $14^{\mathrm{a}}$ Legislatura em 12 de maio de 1871. Rio de Janeiro: Typographia Nacional, 1871. Disponível em: <http://memoria.bn.br/pdf/720968/per720968_1870_00001.pdf>. Acesso em: 27 mai. 2017.

BRASIL. Relatório do ano de 1873 do Ministro dos Negócios do Império, João Alfredo Corrêa de Oliveira. Apresentado à Assembleia Geral Legislativa na $3^{\mathrm{a}}$ sessão da $15^{\mathrm{a}}$ Legislatura em 12 de maio de 1874. Rio de Janeiro: Typographia Nacional, 1874. Disponível em: <http://memoria.bn.br/pdf/720968/per720968_1873_00002.pdf〉. Acesso em: 27 mai. 2017.

BRASIL. Relatório do ano de 1883 do Ministro dos Negócios do Império, Francisco Antunes Maciel. Apresentado à Assembleia Geral na $4^{\mathrm{a}}$ sessão da $18^{\mathrm{a}}$ Legislatura em 3 de maio de 1884 . Rio de Janeiro: Tipografia Nacional, 1884. Disponível em: <http://memoria.bn.br/pd f/720968/per720968_1883_00001.pdf>. Acesso em: 27 mai. 2017. 
BRASIL. Relatório do ano de 1888 do Ministro dos Negócios do Império, Antonio Ferreira Vianna.

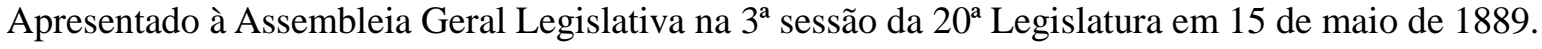
Rio de Janeiro: Typographia Nacional, 1889. Disponível em: <http://memoria.bn.br/pdf/720968/per7 20968_1888_00001.pdf>.Acesso em: 27 mai. 2017.

MUNICÍPIO da Corte. Inspetoria Geral de Instrução Primária e Secundária. Relatório do Inspetor Geral, José Bento da Cunha Figueiredo, de 31 de outubro de 1872. Apresentado ao Ministério dos Negócios do Império e publicado como anexo C do Relatório do ano de 1872 do Ministro dos Negócios do Império, João Alfredo Corrêa de Oliveira, apresentado à Assembleia Geral [na $1^{\mathrm{a}}$ sessão da $15^{\mathrm{a}}$ Legislatura] em aditamento ao de 8 de maio de 1872. Rio de Janeiro: Typographia Nacional, 1872. Disponível em: 〈http://memoria. bn.br/pdf/720968/per720968_1872_00001.pdf〉. Acesso em: 27 mai. 2017.

MINICÍPIO da Corte. Inspetoria Geral de Instrução Primária e Secundária. Relatório do Inspetor Geral interino, Antonio Felix Martins, de 18 de abril de 1874. Apresentado ao Ministério dos Negócios do Império e publicado como anexo B do Relatório do ano de 1873 do Ministro dos Negócios do Império, João Alfredo Corrêa de Oliveira, apresentado à Assembleia Geral na $3^{\text {a }}$ sessão da $15^{\text {a }}$ Legislatura, em 12 de maio de 1874. Rio de Janeiro: Typographia Nacional, 1874. Disponível em: <http://memoria.bn.br/pdf/7209 68/per720968_1873_00003.pdf>. Acesso em: 27 mai. 2017.

MUNICÍPIO da Corte. Inspetoria Geral de Instrução Primária e Secundária. Relatório do Inspetor Geral interino, João Pedro Belfort Vieira, de 31 de dezembro de 1884. Apresentado ao Ministério dos Negócios do Império e publicado como anexo C4-1 do Relatório do Ministro dos Negócios do Império, João Florentino Meira de Vasconcellos, apresentado à Assembleia Geral Legislativa, em 29 de maio de 1885. Rio de Janeiro: Imprensa Nacional, 1885. Disponível em: <http://memo ria.bn.br/pdf/720968/per720968_1884_00001.pdf>. Acesso em: 27 mai. 2017.

Submetido em 21 de Janeiro de 2018. Aprovado em 11 de Julho de 2018. 